\title{
PROPERTY RIGHTS, PROGRESS, AND THE AIRCRAFT PATENT AGREEMENT**
}

\author{
GEORGE BITTLINGMAYER \\ Science Center Berlin
}

\section{INTRODUCTION}

$\mathrm{E}_{\text {Conomists are used to thinking that property rights are a good thing. }}$ Transferable property rights allow resources to be channeled to their most highly valued use, and they allow owners to reap the fruits of their investments. However, property rights also have costs, especially when the rights pertain to ideas and inventions. The aim of this paper is to explore the difficulties that a system of rights to ideas generates, with special reference to the U.S. patent system and to events in the aircraft industry.

A patent pool among aircraft manufacturers was established in 1917, substantially amended in 1928, challenged by the Department of Justice in 1972, and dismantled in a consent decree signed in 1975. It was also the subject of at least four major public investigations during the years 191735 . The pooling agreement made an important subset of each member's aircraft patents available to all other members and stemmed from a patent dispute that originated in 1908 between the Wright brothers and another aviation pioneer, Glenn Curtiss. Patent rights in the agreement were royalty free, except in cases where, in the opinion of a board of arbitration, the patent involved a significant advance. Royalty payments were determined by the board.

The government's charge in 1972 was that the agreement reduced com-

* An earlier version of this paper was presented at the Hoover Conference on Antitrust and Economic Efficiency, August 30, 1984, under the title "Sherman Act Prohibitions and the Gains from Cooperative Effort." Art Denzau, Tom Gilligan, David Haddock, Ed Kitch, Ken Koford, Ben Yu, and especially this journal's referee have provided useful comments. A discussion with Yoram Barzel proved to be very fruitful, and Elizabeth Case's editorial assistance helped me clarify the arguments. Finally, I thank Allen Strehler for unusually thorough research assistance.

[Journal of Law \& Economics, vol. XXXI (April 1988)]

(C) 1988 by The University of Chicago. All rights reserved. 0022/2186/88/3101-0002\$01.50 
petition in airplane innovation. ${ }^{1}$ It seems unlikely that this was the only or even a major effect. Other economic explanations for the agreement emerge by considering it in light of some problems in the economics of property rights. These concern $(a)$ the allocation of returns in the case of bilateral monopoly and in the case of joint effort; $(b)$ the clarity with which limits to rights can be defined; $(c)$ the coordination of access to a public good; $(d)$ the wastes that stem from the competition for a valuable unallocated property right; and $(e)$ the use of long-term contracts to prevent short-term exploitation of one party by another. The first three can be thought of as static, the last two as dynamic issues. While a solution to these problems may involve suppression of the patent system, this will not stifle progress if other, fairly effective mechanisms exist to reward technical innovation. The major features of my argument have analogues in the problem of eminent domain, in the justification for some property (such as roadways) being held in common, and in rationales for long-term contracts and vertical integration.

\section{An Overview of the Welfare Economics of Patent Agreements and Patents}

A brief review of the arguments for and against patent agreements is in order. These arguments, it should be emphasized, take the existing patent system as given and do not question its basic aims and methods.

The most flagrant abuse of a patent cross-licensing or pooling agreement occurs if competitors pool the patents on their common product and then specify price or royalty terms that replicate the effects of a price-

\footnotetext{
1 The aircraft pool apparently ran afoul of the Justice Department's "nine no-no's" of patent licensing. See Bruce B. Wilson, Department of Justice Luncheon Speech, Law on Licensing Practices: Myth or Reality? (January 21, 1975) (remarks delivered before the American Patent Law Association, available from the Department of Justice). The second no-no prohibited a patentee from requiring a licensee to assign to the patentee any after acquired patents-which was effectively the case in the aircraft agreement. Also see Patent Pools-Baker Remarks, 1973 Trade Reg. Rep. (CCH), para. 50, 173, at 55, 313 (remarks of Donald I. Baker before the Banking Law Journal's Fifth Annual Institute on Licensing Law Practices, May 24, 1973): "Where [a pooling arrangement] covers everything in sight, for a very long period of time, it looks increasingly like a sort of non-aggression pact between the various elements in an industry." Baker cited the aircraft agreement as an illustration of a patent pool that "is a sort of insurance arrangement against being out innovated by others." Id . at 55,315 . Interestingly, the aircraft patent cross-license was specifically singled out as a legal patent pool in H. A. Toulmin, Patent Pools and Cross Licenses, 22 Va. L. Rev. 119, 144 (1935); and in Floyd L. Vaughan, The United States Patent System 62 (1956, reprinted 1972). The "nine no-no's" of patent licensing have been repudiated since 1973. See Patent Licensing-Antitrust Division's View, 1984 Trade Reg. Rep. (CCH), para. 50, 446, at 56, 127 (remarks of J. Paul McGrath, Patent Licensing: A Fresh Look at Antitrust Principles in a Changing Economic Environment, given to Seminar Services International Conference on U.S. Patent in Crystal City, Va., April 5, 1984).
} 
fixing agreement. ${ }^{2}$ The monopoly gains in this case are divided as they would be in a classic cartel. It is generally recognized, however, that the existence of competing patents also carries with it the possibility of patent litigation, with its accompanying costs. There is also the possibility that one or more of the patents involved will be held invalid or valid but not infringed. Consequently, a patent agreement may save the expense and uncertainty of litigation, but at the cost of effectively allowing firms to charge consumers for patents that should be competing in the market or that may be invalid in the first place. ${ }^{3}$

Royalty-free cross-licensing or royalty-free pooling of competing patents eliminate this disadvantage and, in the absence of any other restraints, is thought by some analysts to be an unambiguously harmless way of resolving patent disputes. ${ }^{4}$ No money changes hands, making it unlikely that the agreement is a front for a cartel if there are no restrictions on the prices or output of the final product. By widely accepted standards, cross-licensing or pooling of valid complementary or noncompeting patents does not have an anticompetitive effect. ${ }^{5}$

As noted, these arguments take the patent system as given and grant it a fundamentally benign function. But it is an open question whether the patent system always promotes consumer welfare or even whether it always promotes technical progress. After all, the Patent Act is as much a creature of Congress as the Clean Air Act. For example, patent grants may lead to the overutilization of resources in inventive activity, at least for certain kinds of discovery,${ }^{6}$ or they may retard innovation if firms do

${ }^{2}$ George L. Priest, Cartels and Patent License Arrangements, 20 J. Law \& Econ. 309 (1977). Also see the discussion in Richard A. Posner and Frank H. Easterbrook, Antitrust: Cases, Economic Notes, and Other Materials 276-78 (2d ed. 1981).

${ }^{3}$ Ward S. Bowman, Patent and Antitrust Law, 200-201 (1973); Posner and Easterbrook, supra note 2, at 278; and Priest, supra note 2, at 358-59. The idea of "competing patents" is a contradiction in terms. For example, "perfectly competing patents" offer no patent protection. Priest, supra note 2, at 359, raises the issue of "inventions that serve the same function but [that] are separately patentable" without providing an answer. John S. McGee, Patent Exploitation: Some Economic and Legal Problems, 9 J. Law \& Econ. 135, 144-48 (1966), has a provocative analysis of the welfare effects of common control of "competing patents."

${ }^{4}$ Priest, supra note 2, at 377; and McGee, supra note 3, at 153.

${ }^{5}$ Bowman, supra note 3, at 200-201; and Priest, supra note 2, at 357-58.

${ }^{6}$ See the discussion of Arnold Plant's view of patents in Bowman, supra note 3, at 18-23; and Walton Hamilton, Patents and Free Enterprise, U.S. Senate, 76th Cong., 3d Sess., Temporary Economic Committee Monograph No. 31 (1941). Advantages and disadvantages of the patent system are also discussed in William F. Baxter, Legal Restrictions on Exploitation of the Patent Monopoly: An Economic Analysis, 76 Yale L. J. 267, 270-75 (1966); and in Frederic M. Scherer, Industrial Market Structure and Economic Performance 439-58 (2d ed. 1980). A relevant theoretical discussion appears in Yoram Barzel, Optimal Timing of Innovations, 50 Rev. Econ. \& Stat. 348 (1968). 
not publicize discoveries for fear of revealing information that would allow others to patent what the discovering firm had not originally recognized as patentable material. ${ }^{7}$ Regardless of one's views on this issue, it has to be granted that any actual patent system will undoubtedly embody sizeable imperfections judged against an ideal. United States patent law has had shifting standards for what constitutes a patentable invention ${ }^{8}$ and has defined the scope of patents by using technical criteria rather than by addressing questions concerning the more speculative but also more pertinent economic consequences.

It seems reasonable to conclude from these observations that there may be areas where patentability should be abandoned or modified, just as there may be areas where it has not been instituted and should be. As Thomas Jefferson noted: "The irherent problem was to develop some means of weeding out those inventions which would not be disclosed or devised but for the inducement of the patent." ${ }^{, 9}$ Undoubtedly the government's actual system falls short of the mark. If so, privately arranged modifications of the patent system may in some cases represent improvements from the public's point of view. I will leave discussion of the theoretical issues for later and first present the concrete factual background from a case that seems to illustrate what desirable private improvements might look like.

\section{The Aircraft Cross-licensing Agreement}

\section{A. The Wright-Curtiss Dispute and Its Resolution}

The aircraft manufacturers' agreement had its origins in the early days of flight. Orville and Wilbur Wright had solved the problem of lateral stability by watching buzzards fly. They mimicked the wing twisting of gliding birds by constructing a mechanism that warped the horizontal

\footnotetext{
${ }^{7}$ See Jesse W. Markham, Inventive Activity: Government Controls and the Legal Environment, in The Rate and Direction of Inventive Activity: Economic and Social Factors 596-602 (National Bureau of Economic Research 1962) for a review of this issue. George Bittlingmayer, The Application of the Sherman Act to the Smog Patent Agreement, Antitrust Bulletin (forthcoming), has a specific example in which parties to an agreement claimed that the existence of patent protection stifled the exchange and dissemination of technical ideas.

${ }^{8}$ Vaughan, supra note 1, at 19-22. The latitude for shifts in interpretation is evident from an enumeration of the criteria for patentability: originality, novelty, utility, nonobviousness, and, finally, patentability of subject matter. Edmund S. Kitch and Harvey S. Perlman, Legal Regulation of the Competitive Process 797 (1979).

${ }^{9}$ Quoted in Bowman, supra note 3, at 44.
} 
plane of an airplane's wings at either side in opposite directions. ${ }^{10}$ They patented this mechanism and claimed in their patent that their rights extended to any system that varied the "lateral margins" in opposite directions. ${ }^{11}$ The Wrights first flew with this system in 1903.

At the same time, Alexander Graham Bell was conducting flying experiments, providing financial support to, and enlisting the help of others interested in the problem of flight. Among them was a young builder and racer of motorcycles, Glenn Curtiss, who was part of the group because he knew how to make light and powerful engines. ${ }^{12}$ The Bell group was stumped by the problem of lateral control. They knew about the Wright patent but apparently had reservations about the wing-warping method it specified. Bell suggested wing flaps, or "ailerons," which had been used in France. Curtiss subsequently incorporated this concept in his successful flights of 1908 and applied for a patent that incorporated the concept. By 1915, all airplanes used wing flaps instead of the Wright method. Curtiss was officially granted the patent in $1916 .{ }^{13}$

The Wrights sued Curtiss for patent infringement in 1909, claiming that their method applied to wing flaps as well as wing twisting. After protracted litigation, Orville Wright, then the surviving Wright brother, won the case in $1914 .{ }^{14}$ Henry Ford had recently been sued by George Selden, who claimed to have the patent on the automobile, and Ford put Curtiss in touch with Ford's lawyer in the Selden suit, W. Benton Crisp. ${ }^{15}$ Crisp got Curtiss to make a small change in his method of controlling the ailerons, which required the Wright corporation to begin litigating anew. Orville Wright sold out at this point, but the successor company continued to press its claims. With the formal entry of the United States into World War I imminent, however, a solution to the patent litigation was sought by

${ }^{10}$ Flight, History of, 7 Encyclopedia Britannica 380, 387-88 (Macropedia 1983 ed.); Wright, Orville and Wilbur, 19 Encyclopedia Britannica, id. at 1032.

${ }^{11}$ Cecil R. Roseberry, Glenn Curtiss: Pioneer of Flight 62 (1972).

12 Id. at 67-82.

${ }^{13}$ Curtiss's patent was titled "hydroaeroplane" and described a flying boat with wing flaps. It was presumably the first patent to incorporate wing flaps and served as the basis of Curtiss's claim to industry royalties for all airplanes. See the text at notes 22-24 infra.

14 The history of the Curtiss-Wright patent dispute appears in 2 The Papers of Wilbur and Orville Wright 907, 1087-88 n.10, 1092-98 n.11 (Marvin W. McFarland ed. 1953); Fred C. Kelly, The Wright Brothers 287-99 (1943); and Roseberry, supra note 11, at 115, 230, 33262.

15 Roseberry, supra note 11, at 357. The Selden patent case has another connection with the aircraft agreement. Judge John R. Hazel of the District Court of Southern New York, who in 1900 had recognized George Selden as the inventor of the automobile, also upheld the Wrights' claim on the scope of their airplane patent in 1910 and again in 1913. On appeal by Henry Ford, Selden's patent was later held valid but not infringed, while Hazel's decision in the Wright-Curtiss litigation was upheld on appeal in 1915. 
the government since some firms were reluctant to take contracts because of the threat of patent infringement suits. The Wright-Martin Company demanded, and in some cases got, $\$ 1,000$ per airplane and was threatening to sue those considered to be infringers-effectively any airplane manufacturer. ${ }^{16}$

The original request for harmony came in January 1917 from the secretaries of war and the navy. ${ }^{17}$ Following the U.S. declaration of war in April 1917, the National Advisory Committee for Aeronautics proposed a cross-licensing agreement. ${ }^{18}$ The Wright-Martin Company resisted, claiming that it was entitled to large royalties. It eventually yielded and joined the agreement on less ambitious terms when Congress passed legislation that would have condemned the patents. ${ }^{19}$ Crisp was apparently the chief architect of the pool, and he suggested a patent cross-licensing agreement similar to the one that was in effect in the automobile industry. ${ }^{20}$ The patent agreement applied to aircraft structures, excluding engines and instruments, and comprised 130 patents in $1917 .{ }^{21}$

\section{B. Terms of the Cross-licensing Agreement}

The agreement resolved the Wright-Curtiss dispute and made it impossible for a similar dispute to arise among manufacturers who belonged to the association. Each member granted all its airplane patents to all other members. ${ }^{22}$ Members paid a $\$ 1,000$ initiation fee and $\$ 200$ per airplane built, which was distributed as follows: $\$ 135$ to the Wright-Martin Com-

${ }^{16}$ Statement of Brig. Gen. William Mitchell, in Pooling of Patents, Hearings before the Patents Committee, on H.R. 4523 74th Cong., pt. 1, at 3-4 (1936); and Manufacturers Aircraft Ass'n, Inc. v. The United States, 77 C. Cls., at 481, 484 (1933), hereinafter MAA.

17 Howard Mingos, Birth of an Industry 13, 14 (1930), reprinted in The History of the American Aircraft Industry (Gene R. Simonson ed. 1968); and MAA 77 C. Cls., at 484.

${ }^{18}$ Mingos, supra note 17, at 17; and MAA 77 C. Cls., at 485.

19 MAA 77 C. Cls., at 490-91.

20 Mingos, supra note 17; and Roseberry, supra note 11, at 361.

${ }^{21}$ The agreement applied to "heavier-than-air craft, using wing surfaces (and including) power plant appurtenances . . . but not to include the engine and engine accessories." Subsequently, the agreement was amended as new developments occurred. Patents pertaining to sound suppressors, fuel cells, ground effect vehicles, and new types of materials such as plastic were excluded, but exhaust flow deflectors and guided missiles with winged surfaces were included. The eight charter members of the association were: Aeromarine, Burgess, Curtiss, L.W.F. Engineering, Standard Aircraft, Sturtevant, Thomas-Morse, and Wright-Martin. The Dayton Wright Company was added a few months later. Roseberry, supra note 11, at 475 n.2. Mitchell, in Pooling of Patents, supra note 16, at 4, lists seven more firms as having been involved in discussion, but it is not clear if they were ever members.

${ }^{22}$ The 1917 agreement, supplements to it, and the 1928 agreement are reproduced in Pooling of Patents, supra note 16, app., pt. 3, at 3064-3111 (1936). 
pany (the successor to the Wright brothers' firm) until it accumulated $\$ 2$ million or until the Wright patent ${ }^{23}$ (issued in 1906) expired, whichever came first; $\$ 40$ to the Curtiss Company until payments on the Wright patent ceased, after which Curtiss was to receive $\$ 175$ until the total to Curtiss reached $\$ 2$ million or until the Curtiss patent ${ }^{24}$ (issued in 1916) expired; and $\$ 25$ to the association. The $\$ 25$ was to be kept past 1933 , the expiration date of the patent.

All other patents, current and future, were available royalty free to members, except for a special class of future patents to be described. In the event that the government ordered planes from a manufacturer that were based on another manufacturer's design, 1 percent of the purchase price, up to a total payment of $\$ 50,000$ for one model, would go to the original designer. This provision was subsequently dropped. The $\$ 25$ per plane remaining with the association was to go toward operating expenses, the purchase of airplane patents and other activities contributing to the "development of the airplane art and industry," any remainder to be returned to the members. Manufacturers belonging to the association could license their patents to nonmembers if the terms were no more favorable than to members. Any party to the agreement could withdraw, but its patents in the pool at the time of withdrawal would remain there.

It seems worth observing at this point that the total royalty per airplane fell a good deal short of what Wright-Martin had been demanding. The timing of the agreement and its relatively modest royalty terms for the Wright and perhaps the Curtiss patent can probably be attributed to the threat of government action. ${ }^{25}$

An important aspect of the agreement concerned the determination of royalties on "after acquired" patents. Such a patent would be eligible for royalties from members only if it "secures the performance of a function not before known to the art or constitutes an adaptation for the first time to a commercial use of an invention known to the industry to be desirable of use but not used because of lack of adaptation, or is otherwise of striking character or constitutes a radical departure from previous practice, or if either the price paid therefor or the amount expended in developing the same is such as to justify such compensation." The aim appears to have been to define patents more narrowly than was the practice of the

${ }^{23}$ U.S. Patent Office, Orville Wright and Wilbur Wright, Flying Machine, Patent No. 821,393 (1906).

${ }^{24}$ U.S. Patent Office, Glenn H. Curtiss, Hydroaeroplane, Patent No. 1,203,550 (1916).

${ }^{25}$ It may also help to view the agreement against the background of the "association movement," which was then in full swing and which was a response to the antitrust policies of the Taft and Wilson administrations. See Robert F. Himmelberg, The Origins of the National Recovery Administration (1976). 
U.S. Patent Office. There was no appeal to the courts. A board of arbitration determined which patents were eligible and set patent royalties. It was composed of three arbiters, one of whom was appointed by the board of directors of the association, one by the member making a claim, and the third by the other two arbiters. Similar procedures were followed in the event of a dispute between members.

The most important subsequent change I am aware of, the consent decree excepted, occurred with the expiration of the Curtiss patent in 1933, when, in accordance with the 1928 agreement, payments supporting the association were reduced to one-fourth of 1 percent, to cover only operating expenses. ${ }^{26}$ These payments were further reduced in 1935 to one-eighth of 1 percent. Of the 750 patents licensed under the agreement in 1935, 159 had been brought to arbitration in the years from 1929 to 1935. Of these, 87 were refused compensation, and 51 received cash awards. (Decisions on the rest were apparently pending.) Total cumulated royalty payments to 1933 amounted to $\$ 4,360,000$, of which the Curtiss and Wright companies got $\$ 2$ million each. The remaining $\$ 360,000$ went to other patent holders. ${ }^{27}$ On government work, manufacturers had been allowed to use any patent without providing compensation, whether the manufacturer belonged to the association or not, and the patent holder's recourse was the court of claims. ${ }^{28}$ On the other hand, a manufacturer obtained title to any patent that resulted from performing government work, but the government obtained a royalty-free license on the patent.

The agreement survived in this form until 1972, when it was challenged by the Department of Justice. It was abandoned in the 1975 consent decree. ${ }^{29}$ Ironically, the Manufacturers Aircraft Association's cross-

26 Vaughan, supra note 1, at 64.

${ }^{27}$ F. H. Russell, Second Supplemental Statement, in Pooling of Patents, supra note 22, app., pt. 3, at 2977.

28 Vaughan, supra note 1, at 65 . This has been true since 1917 . The difficulty of recovery in the court of claims and the customary "save harmless" clause in government contracts, which shifted liability for any court of claims award back to the manufacturer who built an airplane for the government, were discussed in a number of investigations. See Russell, supra note 27, at 2972; and Inquiry into Operations of the United States Air Services, H.R. 1653, 68th Cong., 2d Sess. (1925).

29 United States v. Manufacturers Aircraft Assn., Civil No. 72 Civ. 1307: MEL, Trade Reg. Rep. (CCH), para. 68, 503. Also see Proposed Consent Judgment and Competitive Impact Statement, 40 Fed. Reg. 30, 848 (1975). The defendants in the case were, in addition to the Manufacturers Aircraft Association, twenty firms: Aeronca, Beech, Bell Aerospace, Boeing, Cessna, Curtiss-Wright, Fairchild Hiller, General Dynamics, Goodyear Aerospace (later dropped as a defendant), Grumman, Kaman, LTV, Lockheed, Martin-Marietta, McDonnell Douglas, North American Rockwell, Northrop, Piper, Ryan, and United Aircraft. 
licensing agreement was one of the most thoroughly investigated patent agreements on record and had received numerous clean bills of health. ${ }^{30}$

\section{The Anticompetitive Potential of the Agreement}

The government claimed in its 1972 suit against the members of the Manufacturers Aircraft Association that the cross-licensing agreement of 1928 hampered competition in research and development and that the amount of research and development in the aircraft industry would have been greater without the agreement. Taking this claim perhaps more seriously than was intended, one might imagine that the aircraft producers were accused of trying to freeze technical progress where it stood in 1917. Of course a zero royalty rate combined with an automatic right to use competitors' patents will, other things being equal, reduce the incentive to produce innovations, at least patentable ones. Other things are not the same, as I will show in Section V, but I first want to examine whether the agreement was well designed to slow progress and increase profits.

${ }^{30}$ Immediately following its organization, a newspaper outcry against the "aircraft trust" ensued in August 1917. The furor over the aircraft trust led to an investigation by the attorney general, who cleared the arrangement in October 1917. The Bureau of Aircraft Production also asked three patent lawyers to survey the agreement, and they concluded that the Curtiss and Wright patents were valid and that the Curtiss and Wright companies were entitled to the royalties stipulated under the agreement. Indignation over the $\$ 200$ per plane royalty persisted, however. At the suggestion of the secretary of the navy, who again raised the possibility of patent condemnation, the agreement was amended to reduce the royalties by half. The navy and war departments also pledged to pay the reduced royalty on any planes they built themselves or had built for them by firms not belonging to the association. Charges concerning an "air trust" continued to be made, however, and these charges led to the formation of a presidential commission chaired by Charles Evans Hughes, a former Supreme Court Justice. This commission again cleared the association and agreement. The "trust" issue was raised once more in 1920 when aircraft manufacturers sought government protection from the sale at low prices of European planes left over from the First World War. The agreement was also the subject of a more extensive investigation in the Lambert committee hearings of 1924, whose final report cleared the association yet again. At the same time, the association was the defendant in an antitrust suit filed by one of the chief accusers in the congressional hearings, James Martin. This suit was dismissed. The association was subjected to additional legal scrutiny in the suit it filed against the government for the government's failure to pay royalties on airplanes it had built for itself or had had others build for it. The association won this case. It was cleared yet again in a presidential report that explicitly held that cross-licensing was beneficial to the U.S. government. The report called the agreement "the very antithesis of monopoly." U.S. Federal Aviation Commission, Message from the President of the U.S., 74th Cong., 1st Sess., Doc. No. 15, at 221 (January 30, 1935). Still another investigation of the aircraft patent pool was conducted in 1935, which again left the agreement intact. This summary stems from: MAA, $77 \mathrm{C}$. Cls., at 481 (1933); Mingos, supra note 17; and Additional Material Submitted to the Committee on Patents by F. H. Russell, in Pooling of Patents, supra note 22, app., at 2962-3001. Russell, at 2964, claims that the pool was investigated at least twenty times between 1917 and 1935 . 
One difficulty with the idea that the aim of the agreement was to hamper progress is that firms were free to compete for customers in other ways. Its effect would have been similar to a price-fixing agreement that left much room for nonprice competition. In this case, however, firms could use price competition to compete away one nonprice restriction, and they could use nonprice competition in nonpatentable aspects of aircraft design and construction, as well as competition in patentable aspects not covered by the agreement (nonstructural aspects of aircraft design). So, for example, they could compete by offering new models based on existing jointly held patents. It also seems important to keep in mind that while aircraft manufacture has always been research intensive to begin with, research efforts can fruitfully be devoted to ends other than developing new patents.

The notion that aircraft manufacturers would restrain themselves in nonpatentable spheres is hard to sustain. Although the industry is and has been concentrated, ${ }^{31}$ a fact which seems to have figured strongly in the government's case, it has also been marked by intense competition. For example, while the four-firm concentration ratio has hovered above 50 percent in recent times, there is considerable instability in market shares. Table 1 shows the market shares of a particular market served by the defendants: in-service aircraft for U.S. passenger airlines from 1932 to 1965. This period covers 70 percent of the period years during which the agreement was in effect. Douglas's share went from zero in 1932 to 93.4 in 1944 and declined to 26.8 in 1965 . Boeing's share increased in the mid-thirties to 28.6, fell for two decades, and then increased again in the 1960s. Similarly, Lockheed's fortunes declined and then revived. Convair and Martin(-Marietta) made good showings in the 1950s, but not before or since. It should be emphasized that these figures pertain to stocks of airplanes and understate substantially the year-to-year fluctuations in sales. The overall demand for long-lived capital goods like airplanes is volatile, even neglecting fluctuations due to swings in defense outlays. These sorts of fluctuations, especially in the case of a product as heterogeneous as airplanes, are widely believed to make the kind of collusion that enriches producers unlikely.

The obvious and radical changes in airplane size, speed, reliability, safety, and comfort that occurred over the years of the agreement also contribute to the impression that the degree of product variety and the

31 The four largest firms in the four-digit Standard Industrial Classification "aircraft" control 58.5 percent of all shipments, the eight largest 81.2 , and the twenty largest 98.6 percent. U.S. Bureau of the Census, Concentration Ratios in Manufacturing, Census of Manufactures 9-116 (1977). 
TABLE 1

Passenger Airline Fleet Shares by Manufacturer, 1932-65

\begin{tabular}{|c|c|c|c|c|c|c|}
\hline Year & Douglas & Boeing & Lockheed & Convair & Martin & Others \\
\hline 1932 & .0 & 19.0 & 8.0 & .8 & .0 & 72.2 \\
\hline 1935 & 17.7 & 28.6 & $\begin{array}{l}0.0 \\
18.1\end{array}$ & $\begin{array}{l}.0 \\
1.9\end{array}$ & .0 & 33.7 \\
\hline 1938 & 61.9 & 16.9 & 19.5 & .0 & .0 & 1.7 \\
\hline 1941 & 81.9 & 9.6 & 8.5 & .0 & .0 & .0 \\
\hline 1944 & 93.4 & .4 & 5.9 & .0 & .0 & .0 \\
\hline 1947 & 92.3 & .7 & 5.8 & .0 & 1.2 & .0 \\
\hline 1950 & 68.7 & 1.9 & 12.2 & 13.0 & 4.2 & .0 \\
\hline 1953 & 50.8 & 1.7 & 15.6 & 20.1 & 11.8 & .0 \\
\hline 1956 & 46.5 & .8 & 17.4 & 20.5 & 9.8 & 5.2 \\
\hline 1959 & 43.8 & 4.5 & 24.5 & 14.0 & 6.8 & 6.4 \\
\hline 1962 & 39.4 & 15.6 & 21.8 & 14.1 & 1.4 & 7.7 \\
\hline 1965 & 26.8 & 36.2 & 17.6 & 11.7 & .0 & 7.7 \\
\hline
\end{tabular}

Source._Almarin Phillips, Technology and Market Structure (1971), table 2-5, at 30. 
TABLE 2

Overlap between Aerospace Patents and Patents in Cross-licensing Agreements

\begin{tabular}{lccc}
\hline \hline Year & $\begin{array}{c}\text { No. of New } \\
\text { Aerospace Patents }\end{array}$ & $\begin{array}{c}\text { No. of New } \\
\text { Patents in Agreement }\end{array}$ & No. in Both \\
\hline 1968 & 315 & 62 & 23 \\
1969 & 338 & 55 & 19 \\
1970 & 291 & 69 & 24 \\
1971 & 336 & 61 & 29 \\
1972 & 268 & 56 & 26 \\
Total & 1,548 & 303 & 121 \\
\hline
\end{tabular}

Source.-Manufacturers Aircraft Association, Documents on file at the Department of Justice, Licensed Airline Patents, Exhibit B; and U.S. Patent and Trademark Office of the U.S. Department of Commerce, Index of Patents (various years) (U.S. Government Printing Office, Washington, D.C.), passim.

rate of progress in aircraft science made it difficult to collude by means of a patent pooling agreement of the sort discussed here; that is, the agreement seems poorly designed to redistribute the gains of trade from consumers to producers. ${ }^{32}$

The available patent data for the last decade and a half of the patent agreement likewise fail to support the idea that the purpose of the agreement was to suppress innovation. The agreement did not dominate patent activity in any of the categories established by the patent office. A total of 303 new patents were added to the agreement over the years 1968-72. Of these, 121 were in patent category 244-aerospace-and these 121 patents accounted for only 7.8 percent of all patents in this category (see Table 2). The remaining patents covered by the agreement were spread over various other patent categories, such as fluid dynamics.

Even in particular subclasses of aerospace patents, those patents assigned to the association only rarely accounted for more than 20 percent of the total, as Table 3 shows. In those categories with the highest fraction

32 Some of these trends are documented in Almarin Phillips, Technology and Market Structure: A Study of the Aircraft Industry (1971). For example, operating costs for pistonpowered aircraft decreased from over 4 cents to about 2 cents per seat-mile (in current dollars) from the 1930s to the 1960s. Costs per seat-mile for jet aircraft had decreased to less than 1.5 cents by the mid-1960s. Capacity for the largest airliner in service in the 1930s was 30 passengers (the Metal Aircraft Corporation's "Flamingo"); by the 1960s, the typical airliner used by domestic trunk lines carried over 100 passengers. Cruising speed increased from less than 200 to over 500 miles per hour between the 1930s and the 1960s. John Newhouse, The Sporty Game (1982), provides accounts of the competition among aircraft manufacturers. This competition appears to take place on the basis of operating efficiency, engineering integrity, configuration, and price. 
TABLE 3

New Aerospace and Patent Pool Patents, 1968-72, by Selected Subclasses in the Aerospace Category

\begin{tabular}{|c|c|c|c|}
\hline Subclass & Abbreviated Description & Pool & All Aerospace \\
\hline 1 & Not elsewhere classified & 1 & 178 \\
\hline 2 & Compound aeronautical machines & 1 & 18 \\
\hline 3 & Compound aeronautical machines & 1 & 4 \\
\hline $3.1-3.7$ & Unmanned missiles & 0 & 126 \\
\hline $4,5,6$ & Various aeronautical machines & 1 & 19 \\
\hline 7 & Helicopters & 9 & 26 \\
\hline 12 & Aeronautical machines sustained with airfoils and jets of air or other fluid & 2 & 41 \\
\hline 13 & Machine sustained by aerodynamic action on airfoil & 3 & 20 \\
\hline $17.11-17.23$ & Gyroplanes, helicopters & 14 & 71 \\
\hline 23 & Machines sustained with jets of air or other fluid & 2 & 32 \\
\hline $30-39$ & Lighter-than-air machines & 0 & 56 \\
\hline $40-45$ & Airfoils, lift devices & 15 & 78 \\
\hline 46 & Provisions for altering arrangement of airfoils & 7 & 25 \\
\hline $47-49$ & Sustaining airfoils & 3 & 14 \\
\hline $50-59$ & Propelling devices, power plants, and power-plant accessories* & 12 & 94 \\
\hline $62-64$ & Propellers, launching devices, human-powered craft & 0 & 25 \\
\hline $73-79$ & Control devices, jets & 4 & 108 \\
\hline $80-89$ & Control systems, airfoils, rudders & 9 & 31 \\
\hline Total & & 84 & 966 \\
\hline All other subclasses & & 37 & 582 \\
\hline Grand total & & 121 & 1,548 \\
\hline
\end{tabular}

Sources. -U.S. Patent and Trademark Office, Classification Definitions, Class 244-Aeronautics (February 1975), passim; Manufacturers Aircraft Association, documents on file at the Department of Justice, Licensed Airline Patents, Exhibit B; and U.S. Patent and Trademark Office of the U.S. Department of Commerce, Index of Patents (various years) (U.S. Government Printing Office, Washington, D.C.), passim

* Includes power plants or accessories incorporated as part of structure and power-plant mounts. 
of patents in the pool (categories 7, 46, and 80-89), investigation revealed that all the other patents (save one) belonged to nonmembers. These were in large part foreign corporations but also included the federal government and independent inventors.

It is of course possible that the patents in the agreement were the only valuable ones within certain areas. The point here is merely that the agreement did not monopolize innovation in even the most narrowly defined subclasses recognized by the patent office. There were also many subclasses in which not a single patent fell under the agreement.$^{33}$ Consequently, if the agreement did hamper progress in some areas, others were left untouched. These results tend to confirm the impression that emerges from the description of the terms of the agreement, namely, that only a restricted set of airplane patents was covered.

This examination of the scope of the agreement and of competitive conditions in the aircraft industry, as well as some straightforward economic agreements, suggest that, if the agreement succeeded in curtailing research and development expenditures, it did so in a limited area of technology, and it did not protect firms from the rigors of competition.

\section{Cooperative Modification of Patent Rights}

Assuming that the monopoly explanation is unsatisfactory, the aircraft patent agreement poses three puzzles:

1. Why would a group of manufacturers, some of whom own patents and some of whom may not, agree to share their current and future patents on a royalty-free basis?

2. Why would such a group provide an arbitration mechanism that selects some patents to receive aribitrated royalties?

3 . Why would the agreement be restricted to patents on aircraft structures and explicitly exclude engines, instruments, and other aircraft components?

I take these questions up from a static viewpoint first.

\section{A. Patents That Fall from Heaven}

The simple answer to the question of when a group of firms will share their patents freely instead of charging for them is axiomatic but instruc-

${ }^{33}$ During the years 1960-72, the following subclasses are among thost that had ten or more new patents of which not even one fell under the agreement: landing gear with wheels (subclass 103), devices for slowing, holding, or restraining aircraft (subclass 110), aircraft seats (subclass 122), and fuel storage and fueling arrangements (subclass 135). Many other subclasses had only one or two patents that were included in the agreement. 
tive. A group of firms will share patents without royalties when each expects to gain more from unrestricted use of other firms' patents than it loses by not being able to charge for its own. This way of stating the issue shows its relationship to another problem: when will members of a group share their secrets? It is also related to the reason university professors do not charge for conversations in the hallway or for the subsequent use of their ideas, whether these are published or not. In this subsection, I will assume that patents are a costless by-product of the firm's activity, that they in effect fall from heaven.

1. Perfectly Efficient Contracts Possible. Imagine a matrix of benefits, in which the element $b_{i j}$ is the benefit to the $i$ th firm of using the $j$ th firm's patents. The simplest assumption is that these benefits are additive. The sum of a column, $\Sigma_{i} b_{i j}$, represents the total value to all firms in the industry of a given firm's patents, and the sum of a row, $\Sigma_{j} b_{i j}$, represents the total value to a given firm of having all patents in the industry available to it royalty free. For a group of firms producing complex, closely related products, a large fraction of the columns will contain positive elements. Let $\Delta b_{i i}$ be the change in the value of a firm's own patents to itself-the change in value of its own discoveries that results when others are allowed to use them at no cost.

A familiar starting point assumes no transactions costs. Can a set of side payments be found that allows each firm to use each patent on which it places a positive value? There are several candidates. Perfect price discrimination would allow efficient use of the patents, as would a price of zero for each patent. The only difference between these two solutions is the allocation of gains, which suggests one difficulty that might crop up in an actual example. The following points seem pertinent.

a) In contrast to some other economic problems, the allocation of the gains from trade is not narrowed or made easier by having more firms involved. This is an implication of the assumption that each patent is unique. Take the simple case in which benefits are additive, all $b_{i j}=1$, and $\Delta b_{i i}=0$. For three firms, the return to any one firm from participating in an industrywide royalty-free agreement is indeterminate over the range from 2 to 5 . The best a firm can do is capture 5 out of a total of 9 for itself, leaving 4 to be split between the other two. The other two firms can always guarantee themselves this total of 4 by splitting off by themselves. By similar arguments, the worst a firm can do is get a gain of only 2 . An analogous calculation for $n=4$ yields a range from 3 to 7 . Although this range per firm expressed as a fraction of the total benefits available is $1 / n$ for arbitrary $n$, it is always equal to the gains that can potentially be provided by one firm to the rest of the industry. 
b) There may of course be interactions among patents, and these interactions are not captured by the assumption of additive patent benefits. Suppose instead that the benefits are multiplicative, so that the benefit to a firm of having a given patent depends on it having all the other patents. (For simplicity, assume that $b_{i j}>1$ for all $i$ and $j$.) Now the potential range of gain for each firm is between zero and the total available to all firms from all the patents. Although multiplicative benefits is an extreme illustration of complementarity of patents-and this could be either complementarity across the technical functions of different patents or the complementarity of earlier and later discoveries ${ }^{34}$ - the economic problem it addresses seems potentially important. From this viewpoint, the rationale for a "private condemnation" of patents that apply to a product is like the rationale for eminent domain. It eliminates difficulties posed by the holdout problem.

c) Another feature of independent contracts between the firms in an industry is that the number of contracts is potentially very large. With $n$ firms, there are $(n-1) n / 2$ bilateral relationships and, assuming only one patent per firm, potentially $(n-1) n$ royalty schedules that have to be negotiated and monitored. One justification for limited patent life is that the number of contracts that would have to be formulated and monitored would be very great with unlimited patent grants. But the optimal patent life surely varies from industry to industry-being shorter in industries with rapid technological advance and in industries with products that embody a large number of patents held by different producers. These factors would tend to tip the balance against pairwise agreements and toward an industrywide agreement.

This simple static conception of the private costs and benefits of a patent agreement is consistent with other rationales for such agreements. One striking feature of patent rights is that the degree to which those rights can be defined is a good deal lower than in the case of, say, land, poetry, or even a trademark. This implies that resources can be used to influence the distribution of net gains. This may be traced in part to a failing of the legal system. In principle, the expenses used to define rights

\footnotetext{
${ }^{34}$ This second possibility suggested itself after I read Ben T. Yu, Potential Competition and Contracting in Innovation, $24 \mathrm{~J}$. Law \& Econ. 215 (1981). Yu focuses on the competition for innovative ideas and the problem of capturing-and, I would add, allocating-returns from sequential innovations. In arguments that I believe to be related to the analysis here, Yu suggests two reasons why private remedies, including royalty-free exchange of rights within an industry, might be desirable: the cost of knowing when future developments can be anticipated varies across industries (this implies it may be difficult to arrange contracts between earlier and later inventors) and enforcement costs in privately enforced contracts may be less. Id. at 231 .
} 
are justifiable if they help channel rewards to inventors whose inventions are sufficiently valuable and would not otherwise become known. However, the lack of clarity in some areas may have carried the struggle for favorable definition past the optimum. ${ }^{35}$

2. Perfectly Efficient Contracts Not Possible. A firm setting prices in its own interests will not set a price of zero and in general will also not be able to practice perfect price discrimination. This implies that it will be able to capture only a fraction of the total gains its patents embody. This is likely to be true even if it charges each user a specially tailored lump sum, or a lump sum plus a per-unit charge. In terms of payoffs that are additive, a firm will only capture a fraction of the sum of each column, $\Sigma_{j \neq i} b_{j i}$. Conversely, it will only receive a fraction of the consumer surplus potentially available to it from other patents, $\Sigma_{j \neq i} b_{i j}$. Let $\alpha$ be the share of total benefits generated by a firm's patents that the firm collects, and $\beta$ the share of benefits on other patents it collects as consumer surplus. For a three-firm example, firm 1 will prefer a royalty-free patent agreement if

$$
\alpha\left(b_{21}+b_{31}\right)+\Delta b_{11}<(1-\beta)\left(b_{12}+b_{13}\right) .
$$

Similar expressions hold for the other two firms. Suppose that the benefits are such that $\alpha=\beta=3 / 8$, implying that $1 / 4$ of the total benefits are lost because of pricing imperfections. Also assume $\Delta b_{11}=0$. A firm will prefer royalty-free licensing if the gains from other patents under free use amount to only 60 percent of the royalty gains potentially available to its patent under perfect price discrimination. To illustrate, the firms in this example will prefer royalty-free cross-licensing if all $b_{i j}=1$. For the case of $n$ firms, for $i=1, \ldots, n$, the general condition analogous to (1) is

$$
\alpha \sum_{j \neq i} b_{j i}+\Delta b_{i i}<(1-\beta) \sum_{j \neq i} b_{i j} \text {. }
$$

35 Timothy F. Bresnahan, Post-entry Competition in the Plain Paper Copier Market, 75 Am. Econ. Rev. 15, 16 (1985), reports that IBM spent millions of dollars to invent around Xerox's major copier patents and that 25 percent of its budget for the project went to patent counsel. Michael Waldholz, Wall St. J., May 17, 1985, at 16, col. 3, claims that "the difficulty of getting uncontested biotech patents has led some large drug companies to avoid certain genetic-engineering research" and reports that two makers of interferon entered into a cross-licensing agreement, apparently to avoid a costly legal battle. One problem the courts seem to have had with aircraft and auto patent rights was in deciding whether a specific patent that incorporates a fundamental general principle should be defined to include all later versions of the product based on that principle. Some judges, like Hazel (see note 15 supra), were inclined to say yes-Selden held the auto patent and the Wrights held the airplane patent-but the courts did not speak with one voice. Ford's ultimate victory in the Selden case illustrates this. 
This analysis of the gains from royalty-free sharing when the use of (positive) prices prevents all of the gains from trade that are ideally available from being realized can be framed in more familiar language. In this static context, a patent right is a public good. There are jointly realizable gains to the firms in an industry from allowing a particular patent to be used in all applications in which its marginal net contribution is greater than zero. A pricing system will generally prevent that, unless prices are zero. While a zero royalty agreement meets the aim of efficiency, it will not take place unless it also meets the aim of individual rationality, which means that inequality (2) must be satisfied for each firm. ${ }^{36}$

Naturally, a firm for which inequality (2) does not hold because the royalties it can command are large can be induced to join with a side payment. This probably explains the payments to the Wright and Curtiss patents. However, if members of the agreement can advance this argument with future patents, they raise the old troublesome issues inherent in the use of positive prices to begin with since each firm would have an incentive to demand a side payment. This illuminates why future patents were included in the agreement. With each new patent a firm would have an incentive to hold its patent out of the agreement and try to find some pricing scheme that would allow it to capture a large share of the total benefits while still getting the other payments for free. Over the course of time the agreement would unravel.

3. The Exclusion of Patents. Two exclusions from royalty-free sharing existed in the agreement: patents of "striking character" received arbitrated royalties, and patents not pertaining to aircraft structures were excluded altogether. One reason for allowing patents of "striking character" to receive royalties arises because firms may believe that the expected value of their current or future patents is so great that they would regret being in the agreement or that they would want to leave it. They can be induced to stay by means of a mechanism that awards them a payment in that event. In this static context the socially optimal point would be complete elimination of patent rights for all patents, but the

\footnotetext{
${ }^{36}$ The inefficiency of charging royalties for what is a public good is discussed in Baxter, supra note 6 , at 274 . The possibility that a royalty-free cross-licensing agreement might be a solution to this inefficiency is not mentioned, however. The notional inefficiency in allocation is also discussed in Kenneth J. Arrow, Economic Welfare and the Allocation of Resources for Invention, in The Rate and Direction of Inventive Activity: Economic and Social Factors at 616-19 (National Bureau of Economic Research 1962). But see Harold Demsetz, Information and Efficiency: Another Viewpoint, 12 J. Law \& Econ. 1 (1969), for a critique of Arrow's policy conclusion that, because of this public good aspect, inter alia, inventive activity should be subsidized by the government.
} 
private interests of the lucky individual firms with very valuable patents will thwart complete dismantlement of patent rights among members. Hence the rights will only be partly trimmed back.

Note, however, that lax patent standards-standards that allow patent grants to ideas that merely fall from heaven-do not explain the arbitrated royalties on patents of "striking character" since the arbitration could have simply been on the question of whether or not to allow a firm to charge as it saw fit for a particular patent. Arbitrated royalties can be better handled, I believe, by (a) appealing to the difficulties posed by the holdout problem, especially when several separately held patents jointly produce a valuable innovation (see the first subsection here); (b) comparing the costs of MAA arbitration proceedings with the patent negotiation and litigation costs that would otherwise take place; or $(c)$ introducing the dynamic issues discussed in the next subsection.

The exclusion of all but aircraft-structure patents from the agreement is consistent with the view that the agreement was aimed at eliminating the holdout problems that arise when the different patents crucial to an innovation are held by different firms. Products such as engines, brakes, and instruments are likely to rely on one patent or a cluster of patents developed by the same inventor. They are often developed and produced by suppliers who are not themselves aircraft producers, or they are often produced by one firm in the industry and sold to the others. These conditions imply that there is less possibility of several patents held by different firms in the industry resulting in a holdout problem. ${ }^{37}$

\section{B. Patents That Are Costly to Develop}

The development and exploitation of patents that are not a costless byproduct of the firm's general business raises two new issues: inefficiency in patent competitions and the monopoly of the successful patent holder. The nature of these two problems can be illuminated with the example of costless contracting. In a world of costless contracting, potential users of a patent would write contracts with potential inventors that specified payment for actual expenditures necessary to develop a patent. These contracts would keep the cost of an innovation equal to the minimum

37 The automobile patent agreement that emerged after the Selden patent dispute (see note 15 supra) also included exceptions for inventions embodying a major technical change (during the first ten years only one such claim was made, which was rejected) and for patents applying to parts manufacturers and to specialized vehicles such as motorcycles and fire engines. See John B. Rae, The American Automobile: A Brief History, 38-39 (1965). 
necessary resource cost. ${ }^{38}$ They would also keep the price of the innovation to the purchaser equal to cost. ${ }^{39}$

The contracts that firms write with their engineers and scientists that grant patent rights to the firms are a simple real-world example of how contracts are used to keep the price of innovations equal to the cost. In many cases, however, neither the exact nature of the invention nor the identity of the inventor is known in advance. And even if the nature of a particular desired technical result is known, claim cannot be laid to it until it is presented in a working form to the patent office. In the meantime, resources can be wasted in a patent competition. ${ }^{40}$

These two points concerning inefficiency in patent competition and the monopoly power of the successful monopolist can be illuminated by drawing a parallel to the function of the court system. The courts can be viewed as supplying the contract terms that are too complicated to specify ex ante for all contingencies. If contracting were costless and if future events were predictable, there would be no role for the courts except contract enforcement. Similarly, the Manufacturers Aircraft Agreement can be thought of as providing contract terms for future inventions. These terms called for zero royalties on more than 90 percent of all patents and low royalties on the rest. These low patent royalties may have regulated the flow of resources into patentable activity - which would provide a benign version of the government's contention that the idea was to limit competition - and they may simultaneously have mimicked the terms that

\footnotetext{
38 It seems unlikely that broad definitions-a patent on the automobile or on the airplane-could be defended on economic grounds. Although the Wright brothers threw their energies into airplane invention in the hope of becoming wealthy - they not only pursued their patent infringement case vigorously but also worked secretively-others, imagining much smaller rewards looming ahead of them, were right behind. The development of a successful flying machine was only a matter of time, and it is unlikely that the introduction of the airplane a few years sooner would have been worth a monopoly grant on the airplane and the consumption of the extra resources that would have been involved in the competition to get it. It is noteworthy that a well-known aviation pioneer, Octave Chanute, who was a mentor to the Wrights, was cool to their dreams of an airplane monopoly and wrote to them that "the value of an invention is whatever it costs to reproduce it." Quoted in Roseberry, supra note 11 , at 64 .

${ }^{39} \mathrm{Yu}$, supra note 34 , examines the problem of contracting for unspecified future innovations, paying particular attention to the problem of sequential innovations.

${ }^{40}$ Barzel, supra note 6 , first pointed to the possibility of a lack of property rights causing too much innovation. Edmund W. Kitch, The Nature and Function of the Patent System, 20 J. Law \& Econ. 265 (1977), suggests that the patent system may serve to prevent this waste from unallocated rights by allowing inventors to stake "prospects." For a contrary view, see Donald G. McFetridge and Douglas A. Smith, Patents, Prospects, and Economic Surplus: A Comment, 23 J. Law \& Econ. 197 (1980); and for a defense see Edmund W. Kitch, Patents, Prospects, and Economic Surplus: A Reply, 23 J. Law \& Econ. 205 (1980).
} 
would have emerged if inventors could bid at low cost for the right to produce future inventions.

A similar argument underlies the government's treatment of patents for military planes. The government condemns patents that it needs for its war planes and allows the manufacturers from which it buys airplanes to use patents that belong to third parties. The patent holders are reimbursed through negotiations or, if those fail, through proceedings in the court of claims. This mechanism can be viewed as a way of preventing a patent holder from capturing the difference between the production cost of a plane and the amount the country is willing to pay for it in time of war. This is economically justified in the sense that, if potential inventors had contracted in advance with the government, they would have been given much less favorable terms than they can extract in wartime.

The public policy question concerning royalty-free or low-royalty rights to patents that are costly to develop is whether the net gains from innovation with patents-left over when gross gains are partially consumed in patent competition, imperfect pricing schemes, and a system of property rights run by the patent office and the courts-are greater than the gross gains from a system in which there are smaller rewards to patents but in which those wastes are largely avoided. How much smaller those gross gains will be depends on the degree to which reductions in royalty payments stifle the development of useful patents. And naturally, it will also depend on the arbitration mechanism used for determining royalties. It does not seem wise to try to provide a decisive answer, but the following points seem worth noting. The total monetary value of innovation, the gross benefits, may be less, but the development costs of patents, the social losses inherent in less-than-perfect prices and in legal costs will almost certainly be less, as will the profits going to successful patent holders. The gains to producers will be greater, otherwise the agreement would not have been entered into. As a matter of arithmetic, the gains to consumers will only decrease if the total amount of innovation is greatly reduced or if low-royalty licensing increases the gains to producers by a sufficiently large amount. ${ }^{41}$

\footnotetext{
41 Vaughan's classic treatise on patents argues that the aircraft agreement, although avoiding patent conflicts, also stifled innovation. However, the two examples he cites do not support his arguments. Vaughan, supra note 1, at 67 . The jet engine, which allegedly came from an independent inventor, fell outside the agreement and was simultaneously being developed abroad anyway. His second example, that the industry failed to contribute to advances in war planes, is, even if true, beside the point since the government directs and finances a good deal of defense research. On the other hand, Glenn Curtiss seemed to think during the period of the early patent disputes that staking out and defending airplane patents may not have been worth the effort. Upon hearing that the Wright brothers had begun to build flying boats, for which he had a patent application pending, Curtiss wrote: "It is not
} 


\section{Concluding Comments}

The aircraft manufacturers' agreement offers challenges to economic theory and to our understanding of the patent system in large part because the agreement seems so poorly designed to further monopoly gain. From the traditional view of patent and antitrust law, the government's case is paradoxical. Patent grants are thought to be "monopolies" and, as such, in uneasy coexistence with antitrust. Yet an agreement whose primary effect was the suspension of patent rights within a certain sphere and the reduction of royalties to less than they would otherwise have been was prosecuted as an antitrust violation.

Economic arguments and the available data give no encouragement to the idea that the aim was to suppress innovation and provide consumers with an inferior product. There are clear, unambiguous welfare advantages to pooling existing patents at zero or low royalty rates. Pooling future patents has the same effects so long as a provision is made for arbitrated royalties that cover the cost of patentable discoveries that would not otherwise be made. The arbitration procedure, used occasionally in the early years for which we have evidence, can be interpreted as an attempt to promote that sort of discovery. Evidence on the instability of market shares, the rate of technical advance, and nonprice competition also makes it seem unlikely that the agreement restricted progress and hurt consumers.

On the arguments advanced here, it makes sense to suppress patent rights if they generate more problems than they solve. A patent system allows inventors to recover more of their costs; it makes it easier for a single, well-defined idea to pass the market test; and it creates a transferable right. The problems emerge partly because of the special nature of invention. Clear boundaries cannot be established-especially in advance-and this invites wasteful competition over the rights to an innovation, both in the courtroom and the laboratory. Because innovative ideas are a special instance of public goods, the benefits of property rights and the use of the price system are obtained at the expense of efficiency in allocation. Another problem is general to a larger class of economic products: how can buyers keep prices paid for goods close to the opportunity costs of providing them? This is likely to be especially troublesome when potential buyers and sellers do not know each other and the nature of the product is difficult to specify in advance.

our desire to monopolize the business, but on such things as we originate we feel we should at least get a royalty so that, if possible, we may be reimbursed for the money we have spent on patents. I am beginning to think, however, that the best plan is to let the patents go, and go after the business." Quoted in Roseberry, supra note 11, at 328 (emphasis added). 